\title{
Effects of Week of Lactation and Genetic Selection for Milk Yield on Milk Fatty Acid Composition in Holstein Cows*
}

\author{
J. K. Kay, ${ }^{1}$ W. J. Weber, ${ }^{2}$ C. E. Moore, ${ }^{1}$ D. E. Bauman, ${ }^{3}$ L. B. Hansen, ${ }^{2}$ \\ H. Chester-Jones, ${ }^{2}$ B. A. Crooker, ${ }^{2}$ and L. H. Baumgard ${ }^{1}$ \\ ${ }^{1}$ Department of Animal Sciences, The University of Arizona, Tucson, 85721 \\ 2Department of Animal Science, The University of Minnesota, St. Paul, 55108 \\ ${ }^{3}$ Department of Animal Science, Cornell University, Ithaca, NY 14853
}

\begin{abstract}
Control (CL) and select line (SL) dairy cows $(\mathrm{n}=22)$ managed identically but differing in milk yield ( $>4100$ $\mathrm{kg} / 305 \mathrm{~d}$ ) were used to determine differences in milk fatty acid profile as lactation progressed. Milk yield was recorded daily and milk samples were collected during wk $1,4,8,12$, and 16 postpartum for milk composition analysis. Milk samples from wk 1, 8, and 16 were also analyzed for fatty acid composition. Select-line cows produced more milk ( $44.4 \mathrm{vs.} 31.2 \mathrm{~kg} / \mathrm{d}$ ) and milk components than CL cows during the 16 -wk period. There was no difference in rate of milk yield increase, but peak milk yield for SL cows was greater and occurred later in lactation. There were no differences in milk SCC or milk fat, protein, or lactose content. Selection for milk yield did not affect the content of most individual milk fatty acids; however, compared with CL, SL cows had a reduced $\Delta^{9}$-desaturase system and tended to produce milk with lower monounsaturated fatty acid content. Selection for milk yield did not affect milk fatty acid origin but the percentage of de novo fatty acids increased and preformed fatty acids decreased as lactation progressed. Milk fat trans-11 18:1 and cis-9,trans11 conjugated linoleic acid increased with progressing lactation (10.7 vs. 14.1 and 3.1 vs. $5.4 \mathrm{mg} / \mathrm{g}$, or 31 and $76 \%$, respectively) and were correlated strongly among wk 1,8 , and 16 of lactation. Temporal changes in the $\Delta^{9}$ desaturase system occurred during lactation but these changes were not correlated with milk fat cis-9,trans11 conjugated linoleic acid content. Results indicate prolonged genetic selection for milk yield had little effect on milk fatty acid composition, but milk fatty acid profiles varied markedly by week of lactation.
\end{abstract}

\footnotetext{
Received March 3, 2005.

Accepted July 8, 2005.

Corresponding author: Lance H. Baumgard; e-mail: baumgard@ag. arizona.edu.

*This work partially supported by the University of Arizona Experiment Station \#ARZT-136339-H-24-130 and the University of Minnesota Experiment Station (project number 16-46 and Regional Project NE-148),
}

(Key words: conjugated linoleic acid, milk fat, genetic selection, dairy cow)

Abbreviation key: $\mathbf{C L}=$ low-merit control line, $\mathbf{C L A}=$ conjugated linoleic acid, SL = high-merit select line, VA = vaccenic acid (trans-11 18:1), WOL $=$ week of lactation.

\section{INTRODUCTION}

Genetic selection of dairy cattle during the last half century has primarily focused on yield traits. The impact of this intense selection for milk yield is expected to decrease component content (Kelm et al., 2000); and our previous studies suggest selection for milk yield has slightly decreased milk fat content (B. A. Crooker, personal communication, 2005), but effects on milk fatty acid profiles have not been reported.

Milk fatty acid content is known to be governed by unique rumen-derived fatty acids (Bauman et al., 2000, 2001) and to vary with stage of lactation and among individual cows (Palmquist et al., 1993). Cows that produce more milk consume more feed, which increases digestive tract passage rates and alters rumen microbial populations (Van Soest, 1982). In addition, homeorhetic mechanisms responsible for the coordinated alterations in tissue metabolism that occur with the onset of lactation may also partition a greater proportion of dietary and tissue-derived nutrients toward milk synthesis. These alterations (rumen and metabolic) could affect the relative contribution of preformed and de novo fatty acids in milk fat from low- and high-merit cows. Selection for increased milk yield therefore has potential to affect milk fatty acid content by altering rumen dynamics and by increasing the magnitude and duration of postpartum tissue mobilization.

Milk fatty acid composition is important for both milk processing and human health. Increased fatty acid unsaturation can lead to oxidization problems for milk product manufacturers, and fatty acids such as conjugated linoleic acid (CLA) and trans-11 18:1 (vaccenic acid; VA) have been linked with health benefits in animal models including reduced incidence of diabetes, 
atherosclerosis, obesity, and cancer (Belury, 2002; Corl et al., 2003).

Recent research focused on enhancing milk fat CLA concentrations has demonstrated that dietary manipulations can alter CLA content at least 5-fold (Bauman et al., 2001; Chilliard et al., 2001). However, large individual animal variation in milk fat CLA content exists (Kelly et al., 1998; Bauman et al., 2001) and the effects of stage of lactation on CLA content are not clear, as some report an increase in CLA content as lactation progresses (MacGibbon et al., 2001; Auldist et al., 2002) and others do not (Kelsey et al., 2003).

The cis-9,trans-11 CLA isomer is produced primarily from endogenous conversion of VA, a biohydrogenation intermediate of linoleic and linolenic acid, via the enzyme $\Delta^{9}$-desaturase (Corl et al., 2001; Kay et al., 2004). Although a small amount of milk fat cis-9,trans-11 CLA originates from the rumen, the 2 main factors believed to influence milk fat cis-9,trans-11 CLA concentration are substrate (VA) availability and mammary $\Delta^{9}$-desaturase activity and/or expression (Bauman et al., 2001).

Because the most dramatic changes in milk fatty acid content occur during early lactation, study objectives were to determine effects of week of lactation (WOL) and selection for increased milk yield on production measures and milk fatty acid composition during the first 16 wk of lactation.

\section{MATERIALS AND METHODS}

\section{Animal Management and Feeding}

Multiparous cows from 2 genetic lines of Holsteins were maintained under identical environment and management practices in free-stall facilities at the University of Minnesota Southeast Experiment Station (Waseca, MN). Development of the static, low-merit control line (CL) and the contemporary, high-merit select line (SL) was initiated in 1964 by Charles Young as a component of a multistate, North Central regional project (NC-2; Hansen, 2000). The original foundation cows were paired by genetic merit and assigned to either low- or high-merit line. The high-merit cows and their female descendants have been inseminated with semen from the highest PTA for milk (PTA-milk) sires $(n=4)$ available each year. From 1964 to 1991, the lowmerit cows and their female descendants were bred with semen from 20 sires (4 sires/yr in a 5-yr rotation) that were breed-average for PTA-milk in 1964. Since 1991, breeding the low-merit cows and their female descendants has continued according to the original design except that semen has been from sons of the original 20 low-merit bulls. Genetic merit for milk yield by low-merit cows has remained stable, whereas genetic merit of high-merit cows has continued to increase
Table 1. Ingredients and formulated composition of the diet.

\begin{tabular}{lc}
\hline Item & Contribution \\
\hline Ingredients (\% of DM) & \\
Alfalfa haylage & 30.3 \\
Corn silage & 19.6 \\
Ground corn & 21.8 \\
Soybean meal/vitamin/mineral mix ${ }^{1}$ & 13.8 \\
Whole cottonseed & 9.7 \\
Alfalfa hay & 4.8 \\
Formulated composition & \\
Dry matter $(\%)$ & 54.8 \\
CP (\% of DM) & 17.3 \\
NDF (\% of DM) & 30.1 \\
ADF (\% of DM) & 21.1 \\
NE $(\mathrm{Mcal} / \mathrm{kg} \mathrm{DM})$ & 1.71 \\
\hline
\end{tabular}

${ }^{1}$ Soybean meal-vitamin-mineral mix contained $5.7 \%$ distillers grain, $2.8 \%$ soybean meal, $1.5 \%$ blood meal, $0.8 \%$ sodium bicarbonate, $0.6 \%$ limestone, $0.6 \%$ tallow, $0.6 \%$ Megalac (Church and Dwight Co., Inc., Princeton NJ), $0.3 \%$ yeast, $0.3 \%$ potassium chloride, $0.2 \%$ trace mineral salt, $0.2 \%$ magnesium oxide, $0.1 \%$ vitamin $\mathrm{A}, \mathrm{D}$, and $\mathrm{E}, 0.1 \%$ dicalcium phosphate, and $0.04 \%$ niacin.

(Jones et al., 1994). Coefficients of inbreeding are not allowed to exceed $6.25 \%$ for low or high-merit cows (Hansen, 2000).

Milk yield of the multiparous CL $(6890 \pm 403 \mathrm{~kg} / 305$ $\mathrm{d}$ lactation) and SL (11,078 $\pm 329 \mathrm{~kg} / 305$-d lactation) cows differed by more than $4100 \mathrm{~kg}$ during this study. Cows ( $10 \mathrm{CL}, 12 \mathrm{SL}$; calving within a 5 -mo period) from 7 CL sires and 10 CL dams and from 8 SL sires and 12 SL dams were fed the same TMR. The TMR was formulated to meet predicted requirements of cows in early lactation (NRC, 2001; Table 1) and ingredients and formulated composition did not differ (data not shown) during the experiment. Dry matter intakes were not measured in the present study; however, previous data (Crooker et al., 2001) using the same herd indicated that SL cows consume more feed than their CL counterparts.

\section{Data Collection and Sample Analyses}

Cows were milked at 12 -h intervals. Milk yield was recorded daily, and weekly averages were used for statistical analysis. Twice-daily milk samples were obtained from each cow on $1 \mathrm{~d}$ during wk $1,4,8,12$, and 16 of lactation. Milk samples from morning milkings were analyzed for fat, lactose, and protein by infrared spectroscopy and for somatic cells by a cell counter (Minnesota DHIA Laboratory, Zumbrota, MN). Evening milk samples from wk 1,8 , and 16 were stored at $-20^{\circ} \mathrm{C}$ without preservative and analyzed for fatty acid composition.

\section{Fatty Acid Analysis}

Milk fat was extracted according to Hara and Radin (1978) and fatty acid methyl esters were prepared by 
Table 2. Effects of week of lactation and selection for milk yield on production variables in lactating dairy cows.

\begin{tabular}{|c|c|c|c|c|c|c|}
\hline \multirow[b]{2}{*}{ Variable } & \multicolumn{2}{|c|}{ Genetic line $(\mathrm{GL})^{1}$} & \multirow[b]{2}{*}{ SEM } & \multicolumn{3}{|c|}{$P$} \\
\hline & CL & SL & & GL & $\mathrm{WOL}^{2}$ & $\mathrm{GL} \times \mathrm{WOL}$ \\
\hline Milk yield, kg/d & 31.2 & 44.4 & 1.0 & $<0.01$ & $<0.01$ & $<0.01$ \\
\hline \multicolumn{7}{|l|}{ Milk fat } \\
\hline$\%$ & 3.49 & 3.70 & 0.14 & 0.30 & $<0.01$ & 0.68 \\
\hline $\mathrm{kg} / \mathrm{d}$ & 1.05 & 1.63 & 0.06 & $<0.01$ & 0.04 & 0.19 \\
\hline \multicolumn{7}{|l|}{ Milk protein } \\
\hline$\%$ & 2.90 & 2.84 & 0.05 & 0.42 & $<0.01$ & 0.95 \\
\hline $\mathrm{kg} / \mathrm{d}$ & 0.87 & 1.25 & 0.03 & $<0.01$ & 0.41 & 0.23 \\
\hline \multicolumn{7}{|l|}{ Milk lactose } \\
\hline$\%$ & 4.81 & 4.88 & 0.07 & 0.47 & $<0.01$ & 0.87 \\
\hline $\mathrm{kg} / \mathrm{d}$ & 1.50 & 2.17 & 0.05 & $<0.01$ & $<0.01$ & 0.01 \\
\hline Milk SCC (linear score) & 2.32 & 2.23 & 0.29 & 0.82 & $<0.01$ & 0.16 \\
\hline
\end{tabular}

${ }^{1} \mathrm{CL}=$ Control line, low-merit cows $(\mathrm{n}=10)$ that represent genetic merit of US Holsteins in 1964; $\mathrm{SL}=$ select line, high-merit cows $(n=12)$ that represent genetic merit of contemporary US Holsteins.

${ }^{2} \mathrm{WOL}=$ Week of lactation.

the transmethylation procedure described by Christie (1982) with modifications (Chouinard et al., 1999). Fatty acid methyl esters were quantified using a gas chromatograph (Hewlett Packard GC system 6890; Wilmington, DE) equipped with a flame-ionization detector and a CP-7489 fused silica capillary column $(100 \mathrm{~m} \times$ $0.25 \mathrm{~mm}$ i.d. with $0.2-\mu \mathrm{m}$ film thickness; Varian, Walnut Creek, CA). Gas chromatograph oven parameters, gas variables, and fatty acid peak identification were as previously described (Moore et al., 2004, 2005).

\section{Calculations and Statistical Analyses}

Effects of genetic line, WOL, and their interaction on milk yield, milk components, and fatty acid profile were analyzed by repeated measures using PROC MIXED procedure of SAS (SAS Institute, 2001) with WOL as the repeated effect and spatial power law (for unevenly spaced data) as the covariance structure. Daily milk yields (1 to 280 DIM) for each cow were fitted to a modified Wood's equation (Ferguson et al., 2000) and coefficients used to generate smooth curves. The smooth curves were used to identify peak milk, days to peak milk, and rates of increase (from calving to peak DIM) and decrease (from peak to 112 and 280 DIM) in daily milk yields for each cow. Effects of genetic line on peak milk, days to peak milk, and rates of increase and decrease in milk yield were analyzed with PROC MIXED procedure of SAS (SAS Institute, 2001). Correlations between individual fatty acids or groups of fatty acids were analyzed using the PROC REG procedure of SAS (SAS Institute, 2001). Results are reported as least squares means, considered significant when $P<0.05$ and reported as a trend when $P<0.15$.

\section{RESULTS}

Cows selected for increased milk yield produced more milk ( $44.4 \mathrm{vs.} 31.2 \mathrm{~kg} / \mathrm{d} ; P<0.01$ ) and milk components than CL cows during the first 16 wk of lactation (Table 2, Figure 1). However, there was no difference in milk component concentrations or SCC between the 2 genetic lines (Table 2). Milk SCC $(P<0.01$, data not presented), milk yield (Figure 1), and the concentration and yield of milk components, except milk protein yield, were affected by WOL (data not presented). There was a genetic line by WOL interaction $(P<0.01)$ for milk yield because peak milk was greater, occurred later, and decreased more slowly through $16 \mathrm{wk}$ of lactation for SL than CL cows (Table 3). Daily milk yield decreased at a similar rate for SL and CL cows from peak to 280 DIM (Table 3).

Selection for milk yield did not alter the content of most individual milk fatty acids (data not presented)

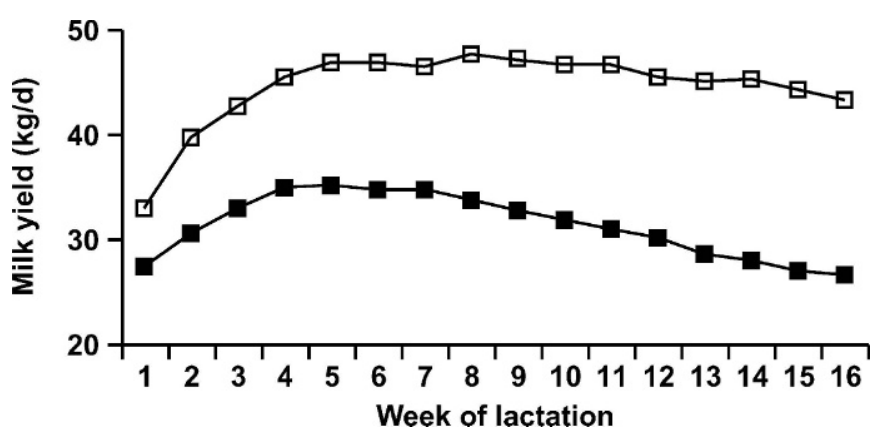

Figure 1. Milk yield $(\mathrm{kg} / \mathrm{d})$ of control low-merit (ם) and select high-merit $(\square)$ cows during wk 1 to 16 of lactation. Control line cows $(\mathrm{n}=10)$ represent genetic merit of US Holsteins in 1964 and select line cows $(n=12)$ represent genetic merit of contemporary US Holsteins. Standard error of the mean averaged 1.2 and ranged from 1.1 to 1.2. 
Table 3. Effect of selection for milk yield on peak milk yield, days to peak milk yield, and rates of milk yield increase to and decrease from peak milk.

\begin{tabular}{lcccr}
\hline & \multicolumn{2}{c}{ Genetic line } & & \\
\cline { 2 - 3 } Variable $^{1}$ & CL & SL & SEM & $P$ \\
\hline Peak milk yield (kg/d) & 35.8 & 47.5 & 1.2 & $<0.01$ \\
Days to peak milk yield & 28.9 & 55.6 & 3.2 & $<0.01$ \\
Rate of milk yield increase (kg/d) & 0.22 & 0.25 & 0.03 & 0.53 \\
Rate of milk yield decrease (peak to 112 DIM, kg/d) & -0.11 & -0.07 & 0.01 & 0.04 \\
Rate of milk yield decrease (peak to 280 DIM, kg/d) & -0.10 & -0.10 & 0.01 & 0.72 \\
\hline
\end{tabular}

${ }^{1}$ Calculated from smooth curves generated for each cow using daily milk yields ( 1 to 280 DIM) and a modified Wood's equation (daily milk yield $=\mathrm{A} \times \mathrm{DIM}^{\mathrm{b}} \times \mathrm{e}^{\mathrm{c} \times \mathrm{DIM}}$ ).

${ }^{2} \mathrm{CL}=$ Control line, low-merit cows $(\mathrm{n}=10)$ that represent genetic merit of US Holsteins in 1964; SL = select line, high-merit cows $(n=12)$ that represent genetic merit of contemporary US Holsteins.

or milk fatty acid origin but CL cows tended $(P<0.12)$ to produce milk with more monounsaturated fatty acids (329 vs. $309 \mathrm{mg} / \mathrm{g}$ of fatty acid) than SL cows (Table 4). However, based on milk fatty acid pairs that represent product/substrate ratios, there was an effect of genetic line on the $\Delta^{9}$-desaturase system (Table 4). Ratios of fatty acid pairs 14:1/14:0 and cis-9 18:1/18:0 were higher $(P<0.05)$, and there was a trend for cis-9 16:1/ 16:0 and the overall $\Delta^{9}$-desaturase ratio to be higher $(P<0.06$ and 0.07 , respectively) in CL compared with SL cows.

Week of lactation markedly affected the content of most individual milk fatty acids (Table 5). Milk fat VA and cis-9,trans-11 CLA concentration increased $(P<$ 0.01 ) from wk 1 to 16 by 3.3 and $2.3 \mathrm{mg} / \mathrm{g}$ or 31 and $76 \%$, respectively. All other individual trans 18:1 fatty acids increased $(P<0.01)$ as lactation progressed re- sulting in a 51\% increase in total trans $18: 1$ fatty acids from wk 1 to 16. Conversely, cis-9 18:1 (oleic acid) decreased $(P<0.01)$ from wk 1 to 16 , due primarily to a $25 \%$ decrease from wk 1 to 8 .

As lactation progressed, the proportion of de novo (sum of 4:0 to 14:1) and mixed origin (sum of 16:0 to 16:1) fatty acids increased $(P<0.01)$, whereas preformed fatty acids (sum $\geq 17: 0)$ decreased $(P<0.01$; Figure 2). All individual $\Delta^{9}$-desaturase ratios except for cis-9,trans-11 CLA/VA decreased $(P<0.01)$ from wk 1 to wk 8 and increased $(P<0.01)$ from wk 8 to 16 of lactation. The cis-9,trans-11 CLA/VA ratio increased ( $P$ $<0.01$ ) from wk 1 to 16 of lactation, whereas the overall $\Delta^{9}$-desaturase index decreased $(P<0.01)$ from wk 1 to 8 but was stable from wk 8 to 16 of lactation (Table 5 ). During the first 16 wk of lactation (independent of the 3 sampling times) there was a strong correlation ( $r=$

Table 4. Effect of selection for milk yield on origin and saturation of milk fatty acids and $\Delta^{9}$-desaturase ratios. $^{1}$

\begin{tabular}{|c|c|c|c|c|}
\hline & \multicolumn{2}{|c|}{ Genetic line $^{2}$} & \multirow[b]{2}{*}{ SEM } & \multirow[b]{2}{*}{$P$} \\
\hline & CL & SL & & \\
\hline \multicolumn{5}{|l|}{ Fatty acid origin, mg/g of fatty acid } \\
\hline De novo & 184.75 & 178.63 & 5.48 & 0.44 \\
\hline $16: 0+16: 1$ & 297.00 & 305.19 & 5.25 & 0.28 \\
\hline Preformed & 490.84 & 486.69 & 8.41 & 0.73 \\
\hline \multicolumn{5}{|l|}{ Fatty acid saturation, mg/g fatty acid } \\
\hline Saturated & 599.62 & 617.63 & 9.04 & 0.17 \\
\hline Monounsaturated & 328.92 & 309.36 & 8.44 & 0.12 \\
\hline Polyunsaturated & 44.04 & 43.53 & 1.47 & 0.80 \\
\hline \multicolumn{5}{|l|}{$\Delta^{9}$-Desaturase ratios } \\
\hline $14: 1 / 14: 0$ & 0.09 & 0.07 & 0.01 & 0.03 \\
\hline $16: 1 / 16: 0$ & 0.06 & 0.05 & $<0.01$ & 0.06 \\
\hline cis-9 18:1/18:0 & 2.09 & 1.80 & 0.09 & 0.04 \\
\hline cis-9,trans-11 conjugated linoleic acid & & & & \\
\hline (CLA)/trans-11 18:1 & 0.36 & 0.34 & 0.01 & 0.18 \\
\hline$\Delta^{9}$-Desaturase index ${ }^{3}$ & 0.37 & 0.35 & 0.01 & 0.07 \\
\hline
\end{tabular}

${ }^{1}$ Data represent means from wk 1,8 , and 16 of lactation.

${ }^{2} \mathrm{CL}=$ Control line, low-merit cows $(\mathrm{n}=10)$ that represent genetic merit of US Holsteins in 1964; $\mathrm{SL}=$ select line, high-merit cows $(\mathrm{n}=12)$ that represent genetic merit of contemporary US Holsteins.

${ }^{3}$ Calculated from $(14: 1+16: 1+$ cis-9 18:1 + cis-9,trans-11 CLA $) /(14: 0+16: 0+18: 0+$ trans-11 18:1 + 14:1

$+16: 1+$ cis-9 18:1 + cis-9, trans-11 CLA). 
Table 5. Effect of week of lactation on milk fatty acid composition. ${ }^{1}$

\begin{tabular}{|c|c|c|c|c|c|}
\hline & \multicolumn{3}{|c|}{ Week of lactation } & \multirow[b]{2}{*}{ SEM } & \multirow[b]{2}{*}{$P$} \\
\hline & 1 & 8 & 16 & & \\
\hline \multicolumn{6}{|l|}{ Fatty acid, mg/g of fatty acids } \\
\hline $4: 0$ & $28.14^{\mathrm{a}}$ & $26.10^{\mathrm{b}}$ & $21.84^{\mathrm{c}}$ & 0.55 & $<0.01$ \\
\hline $6: 0$ & $18.74^{\mathrm{a}}$ & $24.73^{\mathrm{b}}$ & $22.42^{\mathrm{c}}$ & 0.66 & $<0.01$ \\
\hline $8: 0$ & $7.35^{\mathrm{a}}$ & $11.78^{\mathrm{b}}$ & $11.52^{\mathrm{b}}$ & 0.40 & $<0.01$ \\
\hline $10: 0$ & $11.50^{\mathrm{a}}$ & $21.25^{\mathrm{b}}$ & $23.57^{\mathrm{c}}$ & 0.89 & $<0.01$ \\
\hline $12: 0$ & $12.11^{\mathrm{a}}$ & $22.12^{\mathrm{b}}$ & $25.86^{\mathrm{c}}$ & 0.92 & $<0.01$ \\
\hline $14: 0$ & $52.21^{\mathrm{a}}$ & $77.64^{\mathrm{b}}$ & $90.86^{\mathrm{c}}$ & 2.37 & $<0.01$ \\
\hline $14: 1$ cis -9 & $4.53^{\mathrm{a}}$ & $5.50^{\mathrm{b}}$ & $7.30^{\mathrm{c}}$ & 0.27 & $<0.01$ \\
\hline $15: 0$ & $4.17^{\mathrm{a}}$ & $6.45^{\mathrm{b}}$ & $7.41^{\mathrm{c}}$ & 0.19 & $<0.01$ \\
\hline $16: 0$ & $270.19^{\mathrm{a}}$ & $295.22^{\mathrm{b}}$ & $294.68^{\mathrm{b}}$ & 4.57 & $<0.01$ \\
\hline $16: 1$ cis -9 & $19.64^{\mathrm{a}}$ & $10.45^{b}$ & $13.11^{\mathrm{c}}$ & 0.79 & $<0.01$ \\
\hline $17: 0$ & $6.80^{\mathrm{a}}$ & $5.03^{b}$ & $4.37^{\mathrm{c}}$ & 0.14 & $<0.01$ \\
\hline 18:0 & $151.95^{\mathrm{a}}$ & $144.88^{\mathrm{a}}$ & $122.32^{\mathrm{b}}$ & 4.21 & $<0.01$ \\
\hline $18: 1$ trans $-6-8$ & $3.80^{\mathrm{a}}$ & $4.97^{\mathrm{b}}$ & $5.52^{\mathrm{c}}$ & 0.15 & $<0.01$ \\
\hline $18: 1$ trans -9 & $2.81^{\mathrm{a}}$ & $4.04^{\mathrm{b}}$ & $4.50^{\mathrm{c}}$ & 0.11 & $<0.01$ \\
\hline $18: 1$ trans -10 & $4.32^{\mathrm{a}}$ & $6.80^{\mathrm{b}}$ & $7.41^{\mathrm{c}}$ & 0.25 & $<0.01$ \\
\hline 18:1 trans -11 & $10.72^{\mathrm{a}}$ & $12.85^{\mathrm{b}}$ & $14.06^{\mathrm{b}}$ & 0.69 & $<0.01$ \\
\hline 18:1 trans -12 & $4.63^{\mathrm{a}}$ & $8.13^{\mathrm{b}}$ & $8.17^{\mathrm{b}}$ & 0.24 & $<0.01$ \\
\hline $18: 1$ cis -9 & $314.64^{\mathrm{a}}$ & $237.29^{\mathrm{b}}$ & $242.23^{\mathrm{b}}$ & 6.95 & $<0.01$ \\
\hline $18: 2$ cis-9,cis- 12 & $33.38^{\mathrm{a}}$ & $33.91^{\mathrm{a}}$ & $37.93^{\mathrm{b}}$ & 0.94 & $<0.01$ \\
\hline 18:2 cis-9,trans-11 conjugated linoleic acid (CLA) & $3.09^{\mathrm{a}}$ & $4.60^{\mathrm{b}}$ & $5.43^{\mathrm{c}}$ & 0.24 & $<0.01$ \\
\hline 18:3 cis- 9, cis -12, cis -15 & 4.31 & 4.29 & 4.42 & 0.17 & 0.75 \\
\hline 20:0 & $0.80^{\mathrm{a}}$ & $0.95^{\mathrm{b}}$ & $0.94^{\mathrm{ab}}$ & 0.04 & 0.05 \\
\hline Unknown $^{2}$ & $30.16^{\mathrm{a}}$ & $31.02^{\mathrm{a}}$ & $24.17^{\mathrm{b}}$ & 1.20 & $<0.01$ \\
\hline \multicolumn{6}{|l|}{$\Delta^{9}$-Desaturase ratios } \\
\hline 14:1/14:0 & $0.09^{\mathrm{a}}$ & $0.07^{\mathrm{b}}$ & $0.08^{\mathrm{a}}$ & $<0.01$ & $<0.01$ \\
\hline $16: 1 / 16: 0$ & $0.08^{\mathrm{a}}$ & $0.04^{\mathrm{b}}$ & $0.05^{\mathrm{c}}$ & $<0.01$ & $<0.01$ \\
\hline$c i s-9$ 18:1/18:0 & $2.17^{\mathrm{a}}$ & $1.67^{\mathrm{b}}$ & $2.01^{\mathrm{a}}$ & 0.08 & $<0.01$ \\
\hline cis-9, trans-11 CLA/trans11 18:1 & $0.29^{\mathrm{a}}$ & $0.36^{\mathrm{b}}$ & $0.39^{\mathrm{c}}$ & 0.01 & $<0.01$ \\
\hline$\Delta^{9}$-Desaturase index ${ }^{3}$ & $0.41^{\mathrm{a}}$ & $0.33^{\mathrm{b}}$ & $0.34^{\mathrm{b}}$ & 0.01 & $<0.01$ \\
\hline
\end{tabular}

${ }^{\mathrm{a}, \mathrm{b}, \mathrm{c}}$ Different superscripts within a row indicate differences, $P<0.05$.

${ }^{1}$ Data represent means from control line, low-merit cows $(n=10)$ that represent genetic merit of US Holsteins in 1964 and select line, high-merit cows $(n=12)$ that represent genetic merit of contemporary US Holsteins.

${ }^{2}$ Represents unidentified fatty acids.

${ }^{3}$ Calculated from $(14: 1+16: 1+$ cis-9 18:1 + cis-9, trans-11 CLA $) /(14: 0+16: 0+18: 0+$ trans-11 18:1 + $14: 1+16: 1+$ cis-9 18:1 + cis-9, trans-11 CLA).

$0.63 ; P<0.01$ ) between milk fat VA and cis-9,trans-11 CLA (Figure 3). However, based on the $\Delta^{9}$-desaturase index there was a small but significant correlation $(\mathrm{r}=$ $0.13 ; P<0.01$ ) between milk cis-9,trans-11 CLA and the $\Delta^{9}$-desaturase system (Figure 4 ).

\section{DISCUSSION}

Genetic selection for milk yield increased milk and milk component yields, but did not alter the concentration of milk solids (fat, protein, and lactose) or SCC over the first $16 \mathrm{wk}$ of lactation. The similar concentration of milk fat between the SL and CL cows differs from our previous studies (B. A. Crooker, personal communication, 2005), which indicated less milk fat from multiparous SL than CL cows. Reasons for the disparity in milk fat percentages among the current study, other selection trials (Kelm et al., 2000), and our previous results are unknown but may be the result of the small number of animals used. Although increased milk yield is loosely associated with greater susceptibility to mastitis (Schutz, 1994; Hansen, 2000), the similar SCC for SL and CL cows indicates that any difference between lines in subclinical and clinical mastitis was minimal and did not contribute to differences in variables evaluated in this study.

As expected, effects of WOL on milk yield and milk components in the present study were typical for cows transitioning through the first $16 \mathrm{wk}$ of lactation. The major change in milk components occurred from wk 1 to 4 with a decrease in fat and protein content and an increase in lactose content (data not presented). There was an interaction of WOL by genetic line for milk yield in that SL cows produced more milk and peaked later in lactation whereas milk yield of CL cows decreased more rapidly than SL cows through wk 16 of lactation (Tables 2 and 3; Figure 1). This difference in persistency between the lines is an artifact of the short interval 


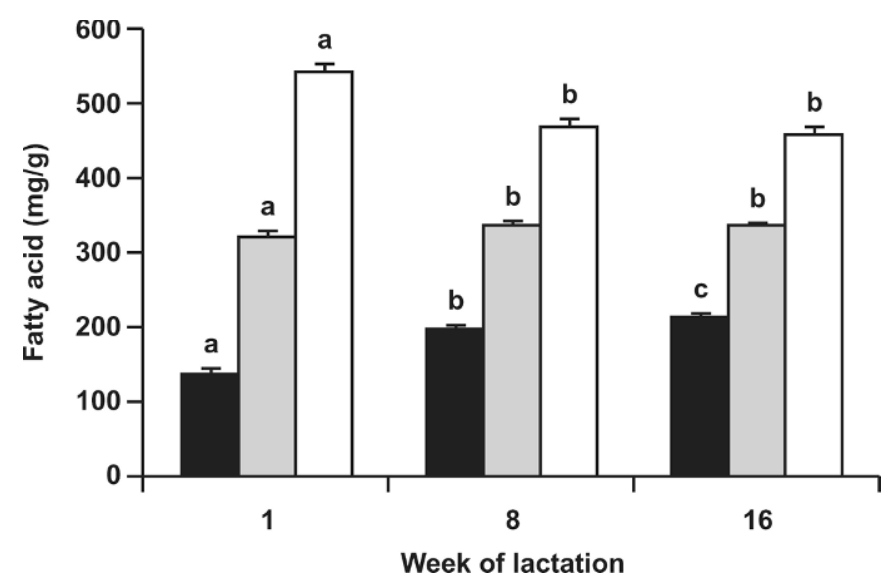

Figure 2. Milk fatty acid origin during wk 1 to 16 of lactation. Origins are calculated as de novo (sum of 4:0 to 15:0; black bar), sum of 16:0 + 16:1 (gray bar), and preformed ( $\geq 17: 0$; white bar). Data are least squares means from wk 1,8 , and 16 of lactation from control line, low-merit cows $(n=10)$ that represent genetic merit of US Holsteins in 1964 and select line, high-merit cows $(\mathrm{n}=12)$ that represent genetic merit of contemporary US Holsteins. Selection for increased milk yield did not affect origin of milk fatty acids. Different superscripts on the same color bar indicate week of lactation differences $(P<0.05)$.

from peak milk to wk 16 as persistency between the lines was similar when measured from peak milk to 280 DIM (Table 3).

Greater milk production in genetically superior cows has been attributed to increased homeorhetic coordination and use of tissue-derived nutrients in early lactation and greater proportions of dietary energy partitioned toward milk production (Bauman et al., 1985;

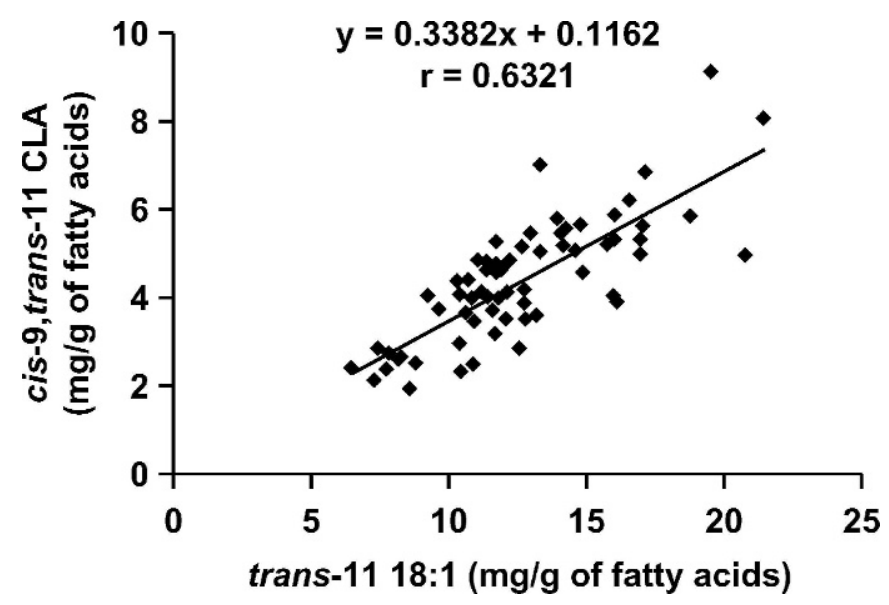

Figure 3. Relationship between milk fat cis-9, trans-11 conjugated linoleic acid (CLA) and trans-11 18:1 content during wk 1, 8, and 16 of lactation of control line, low-merit cows $(n=10)$ that represent genetic merit of US Holsteins in 1964 and select line, high-merit cows $(\mathrm{n}=12)$ that represent genetic merit of contemporary US Holsteins. Selection for milk yield did not alter the relationship.

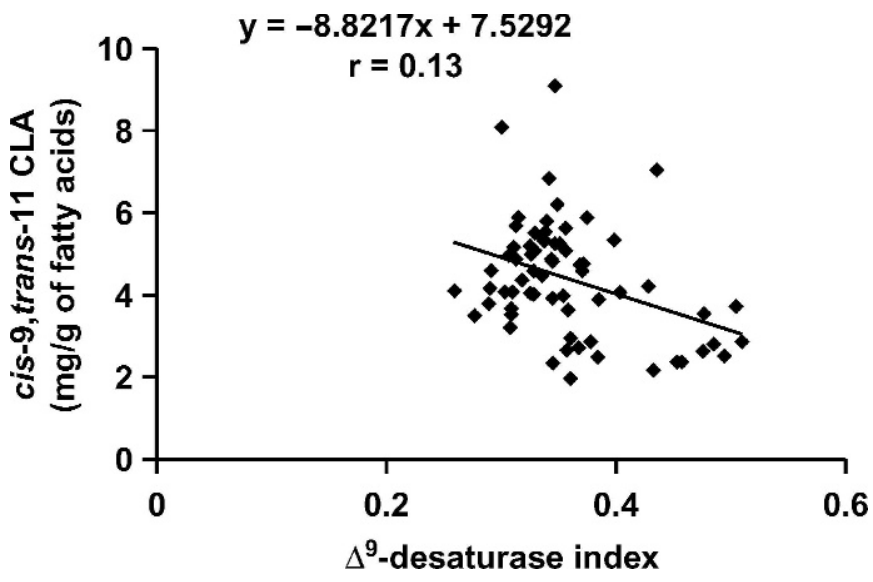

Figure 4. Relationship between milk fat cis-9,trans-11 conjugated linoleic acid (CLA) and $\Delta^{9}$-desaturase activity and expression (based on $\Delta^{9}$-desaturase index) during wk 1,8 , and 16 of lactation for control line, low-merit cows $(n=10)$ that represent genetic merit of US Holsteins in 1964 and select line, high-merit cows $(\mathrm{n}=12)$ that represent genetic merit of contemporary US Holsteins. Selection for milk yield did not alter the relationship.

Collier et al., 2005). Therefore, we hypothesized that milk from high-merit SL cows during early lactation would have greater proportions of preformed fatty acids, due to increased adipose tissue mobilization. However, despite the greater yield of milk and milk fat, there was no effect of selection for milk yield on milk fatty acid origin during the first 16 wk of lactation, on either a molar percentage (data not presented) or concentration basis, with both genetic lines showing similar temporal patterns. In support of this, recent studies with these genetic lines have demonstrated that multiparous CL and SL cows have similar energy balance measures, circulating NEFA concentrations, and whole body response to lipolytic stimuli during the periparturient period (Crooker et al., 2001). Those data and results from the present study suggest that the primary mechanism by which genetic selection mediates enhanced milk yield is increased energy intake and improved use of absorbed nutrients for milk synthesis rather than increased adipose tissue mobilization.

Although on average, de novo fatty acids comprise approximately $40 \%$ by weight or $60 \%$ on a molar basis over the entire lactation (Bauman and Davis, 1974), preformed fatty acids generally contribute a larger portion of the total fatty acids in early lactation. As lactation progresses, the contribution from de novo synthesized fatty acids increases (Palmquist et al., 1993). In the current study, de novo fatty acids synthesis increased from wk 1 to 16 with the most dramatic increase occurring from wk 1 to 8 . This general pattern held true for all de novo synthesized fatty acids other than butyrate, which decreased slightly over time. However, 
butyrate can arise from 2 pathways independent of the acetyl coenzyme A carboxylase pathway and may not be inhibited by increased intracellular NEFA concentrations (Palmquist et al., 1993) associated with early lactation.

As expected, due to increased adipose tissue mobilization immediately postpartum, preformed fatty acid concentrations were greatest in wk 1 , decreased in wk 8 , and remained constant through wk 16 . Stearic and oleic acids were primarily accountable for this response. Oleic acid, the predominant fatty acid in adipocytes, and the primary fatty acid released from adipocytes during lipolysis (Rukkwamsuk et al., 2000; Gillis et al., 2004 ), decreased by $25 \%$ from wk 1 to 8 .

The concept of dairy products as functional foods has gained much attention due largely to health benefits associated with cis-9,trans-11 CLA and its precursor, VA (Belury, 2002; Corl et al., 2003; Lock and Bauman, 2004). The effect of genetic selection for milk yield on these specific milk fatty acids (and consequently the health properties of milk) have not previously been investigated. This study demonstrates that prolonged selection for increased milk yield did not alter the content of cis-9,trans-11 CLA, VA, or the majority of individual milk fatty acids. There was, however, a WOL effect as milk fat cis-9,trans-11 CLA and VA concentrations increased by 76 and $31 \%$ (3.1 vs. 5.4 and 10.7 vs. 14.1 $\mathrm{mg} / \mathrm{g}$ ) respectively, from wk 1 to 16 . These increases were not the result of dietary changes as all cows consumed the same TMR (Table 1) throughout the first 16 wk of lactation.

These increases in milk cis-9,trans-11 CLA and VA content support findings from MacGibbon et al. (2001). However, results from the aforementioned pasturebased experiments were confounded by diet because total unsaturated and linolenic fatty acids are greater in spring and fall pastures compared with summer pastures (Thomson et al., 2002). To control for these variables, Auldist et al. (1998) repeatedly sampled milk from 4 grazing herds that calved at 4 distinct stages during the year and observed a $23 \%$ increase in milk fat CLA content from early ( $\sim 30$ DIM) to late ( 210 DIM) lactation. In contrast, Kelsey et al. (2003) included data from more than 200 dairy cows that were fed the same diet and sampled on 1 calendar day. They reported that milk fat CLA content was not affected by stage of lactation. A limitation of the later study was that only a single milk sample was obtained from each cow. Because cis-9,trans-11 CLA can vary by as much as 5 -fold in individual cows fed the same diet (Bauman et al., 2001; Chilliard et al., 2001), the ability of that study to detect effects of stage of lactation may have been limited. Therefore, the benefits of the present study and that of Auldist et al. (1998) were that multiple and repeated samples were obtained (while diet remained essentially constant), which allowed us to account for individual animal variation and hence, have a more sensitive test to detect effects of stage of lactation.

The majority of $c i s-9$,trans-11 CLA is produced endogenously via $\Delta^{9}$-desaturation of VA; thus, milk fat cis9 ,trans-11 CLA can be elevated by increasing VA supply to the mammary gland or increasing $\Delta^{9}$-desaturase activity and/or expression. We detected a strong $(\mathrm{r}=0.63$; $P<0.01)$ correlation between milk fat cis-9,trans-11 CLA and VA content (Figure 3), which agrees with previous reports (Bauman et al., 2000, 2001). However, the correlation between cis-9,trans-11 CLA content and the $\Delta^{9}$-desaturase system was weak $(\mathrm{r}=0.13 ; P<0.01)$, whether evaluated using the overall $\Delta^{9}$-desaturase index or individual fatty acid pairs that represent product/substrate ratios for $\Delta^{9}$-desaturase system (data not presented). Although the range in the $\Delta^{9}$-desaturase index was small ( $\sim 0.27$ to 0.55 ; Figure 4$)$ and may not provide an accurate description of the enzyme's upper and lower critical limits, these results suggest that the increase in cis-9,trans-11 CLA as lactation progressed from wk 1 to 16 was due primarily to increased VA delivery to the mammary gland rather than changes in the $\Delta^{9}$-desaturase system. This agrees with our recent data demonstrating that increased cis-9,trans-11 CLA content in milk fat from pasture-fed cows compared with cows fed TMR is due predominantly to increased ruminal VA production and, to a lesser extent, increased $\Delta^{9}$-desaturase activity and/or expression (Kay et al., 2005).

Milk fat content of other trans 18:1 isomers also increased as lactation progressed. This is probably the result of incomplete rumen biohydrogenation, possibly due to increased feed intake and rumen passage rates as typically observed with advancing lactation. This is also supported by the decreasing milk fat stearic acid content (the end product of biohydrogenation of polyunsaturated fatty acids) as lactation advanced.

\section{CONCLUSIONS}

Prolonged selection for milk yield had little or no effect on milk composition, SCC, or milk fatty acid profile. However, milk yield, milk composition, and origin of milk fat were influenced greatly by week of lactation. The increase ( $3.1 \mathrm{vs} .5 .4 \mathrm{mg} / \mathrm{g}$ or $76 \%$ ) in milk fat cis9,trans-11 CLA from wk 1 to 16 of lactation was primarily due to an increased supply of VA during this interval and not to an increase in overall mammary $\Delta^{9}$-desaturase system.

\section{ACKNOWLEDGMENTS}

The technical assistance of Sara Sanders was greatly appreciated. Excellent animal care and courteous assis- 
tance throughout the study was provided by David Ziegler and the rest of the staff at the University of Minnesota, Southern Research and Outreach Center at Waseca, MN.

\section{REFERENCES}

Auldist, M. J., J. K. Kay, N. A. Thomson, A. R. Napper, and E. S. Kolver. 2002. Concentrations of CLA in milk from cows grazing pasture or fed a total mixed ration for an entire lactation. Proc. N.Z. Soc. Anim. Prod. 62:240-241.

Auldist, M. J., B. J. Walsh, and N. A. Thomson. 1998. Seasonal and lactation influences on bovine milk composition in New Zealand. J. Dairy Res. 65:401-411.

Bauman, D. E., L. H. Baumgard, B. A. Corl, and J. M. Griinari. 2000. Biosynthesis of conjugated linoleic acid in ruminants. Proc. Am. Soc. Anim. Sci., 1999. Available at: http://www.asas.org/jas/ symposia/proceedings/0937.pdf.

Bauman, D. E., B. A. Corl, L. H. Baumgard, and J. M. Griinari. 2001. Conjugated linoleic acid (CLA) and the dairy cow. Pages 221-250 in Recent Advances in Animal Nutrition. P. C. Garnsworthy and J. Wiseman, ed. Nottingham University Press, Nottingham, UK.

Bauman, D. E., and C. L. Davis. 1974. Biosynthesis of milk fat. Pages 31-75 in Lactation: A Comprehensive Treatise. B. L. Larson, ed. Academic Press, New York, NY.

Bauman, D. E., S. N. McCutcheon, W. D. Steinhour, P. J. Eppard, and S. J. Sechen. 1985. Sources of variation and prospects for improvement of productive efficiency in the dairy cow: A review. J. Anim. Sci. 60:583-592.

Belury, M. A. 2002. Dietary conjugated linoleic acid in health: Physiological effects and mechanisms of action. Annu. Rev. Nutr. 22:505-531.

Chilliard, Y., A. Ferlay, and M. Doreau. 2001. Effect of different types of forages, animal fat or marine oils in cow's diet on milk fat secretion and composition, especially conjugated linoleic acid (CLA) and polyunsaturated fatty acids. Livest. Prod. Sci. 70:31-48.

Chouinard, P. Y., L. Corneau, A. Saebo, and D. E. Bauman. 1999. Milk yield and composition during abomasal infusion of CLA. J. Dairy Sci. 82:2737-2745.

Christie, W. W. 1982. A simple procedure for rapid transmethylation of glycerolipids and cholesteryl esters. J. Lipid Res. 23:1072-1075.

Collier, R. J., L. H. Baumgard, A. L. Lock, and D. E. Bauman. 2005. Physiological Limitations: Nutrient partitioning. Pages 351-377 in Yield of Farmed Species: Constraints and opportunities in the 21st century. Proc. 61st East School, Nottingham, UK. J. Wiseman and R. Bradley, ed. Nottingham University Press, Nottingham, UK.

Corl, B. A., D. M. Barbano, D. E. Bauman, and C. Ip. 2003. Cis-9, trans-11 CLA derived endogenously from trans-11 18:1 reduces cancer risk in rats. J. Nutr. 133:2893-2900.

Corl, B. A., L. H. Baumgard, D. A. Dwyer, J. M. Griinari, B. S. Phillips, and D. E. Bauman. 2001. The role of $\Delta^{9}$-desaturase in the production of cis-9, trans-11 CLA. J. Nutr. Biochem. 12:622-630.

Crooker, B. A., W. J. Weber, L. S. Ma, and M. C. Lucy. 2001. Effect of energy balance and selection for milk yield on the somatotropic axis of the lactating Holstein cow: Endocrine profiles and hepatic gene expression. Pages 345-348 in Energy Metabolism of Animals (15th Symposium). EAAP Energy Symposium, Snekkersten, Denmark. Publ. No. 103. EAAP, Rome, Italy.

Ferguson, J. D., D. K. Beede, R. D. Shaver, C. E. Polan, J. T. Huber, and P. T. Chandler. 2000. A method to analyze production responses in dairy herds. J. Dairy Sci. 83:1530-1542.
Gillis, M. H., S. K. Duckett, and J. R. Sackmann. 2004. Effects of supplemental rumen-protected conjugated linoleic acid or corn oil on fatty acid composition of adipose tissues in beef cattle. J. Anim. Sci. 82:1419-1427.

Hansen, L. B. 2000. Consequences of selection for milk yield from a geneticist's viewpoint. J. Dairy Sci. 83:1145-1150.

Hara, A., and N. S. Radin. 1978. Lipid extraction of tissues with a low-toxicity solvent. Anal. Biochem. 90:420-426.

Jones, W. P., L. B. Hansen, and H. Chester-Jones. 1994. Response of health care to selection for milk yield of dairy cattle. J. Dairy Sci. 77:3137-3152.

Kay, J. K., E. S. Kolver, N. A. Thomson, J. R. Roche, and L. H. Baumgard. 2005. The effect of vitamin E supplementation on production and fatty acid profiles. J. Dairy Res. 72:1-11.

Kay, J. K., T. R. Mackle, M. J. Auldist, N. A. Thomson, and D. E. Bauman. 2004. Endogenous synthesis of cis-9, trans-11 CLA in dairy cows fed fresh pasture. J. Dairy Sci. 87:369-378.

Kelly, M. L., E. S. Kolver, D. E. Bauman, M. E. Van Amburgh, and L. D. Muller. 1998. Effect of intake of pasture on concentrations of conjugated linoleic acid in milk of lactating dairy cows. J. Dairy Sci. 81:1630-1636.

Kelm, S. C., A. E. Freeman, and NC-2 Technical Committee. 2000. Direct and correlated responses to selection for milk yield: Results and conclusions of regional project NC-2, "Improvement of dairy cattle through breeding, with emphasis on selection." J. Dairy Sci. 83:2721-2732.

Kelsey, J. A., B. A. Corl, R. J. Collier, and D. E. Bauman. 2003. The effect of breed, parity, and stage of lactation on conjugated linoleic acid (CLA) in milk fat from dairy cows. J. Dairy Sci. 86:2588-2597.

Lock, A. L., and D. E. Bauman. 2004. Modifying milk fat composition of dairy cows to enhance milk fatty acids beneficial to human health. Lipids 39:1197-1206.

MacGibbon, A. K. H., Y. E. H. van der Does, B. Y. Fong, N. P. Robinson, and N. A. Thomson. 2001. Variations in the CLA content of New Zealand milk fat. Aust. J. Dairy Sci. 56:158.

Moore, C. E., H. C. Hafliger, III, O. B. Mendivil, S. R. Sanders, D. E. Bauman, and L. H. Baumgard. 2004. Increasing amounts of conjugated linoleic acid (CLA) progressively reduce milk fat synthesis immediately postpartum. J. Dairy Sci. 87:1886-1895.

Moore, C. E., J. K. Kay, M. J. VanBaale, R. J. Collier, and L. H. Baumgard. 2005. Effect of conjugated linoleic acid on heatstressed Brown Swiss and Holstein cattle. J. Dairy Sci. 88:1732-1740.

National Research Council. 2001. Nutrient Requirements of Dairy Cattle. 7th rev. ed. National Academy of Sciences, Washington, DC.

Palmquist, D. L., A. D. Beaulieu, and D. M. Barbano. 1993. ADSA foundation symposium: Milk fat synthesis and modification. Feed and animal factors influencing milk fat composition. J. Dairy Sci. 76:1753-1771.

Rukkwamsuk, T., M. J. H. Geelen, T. A. M. Druip, and T. Wensing. 2000. Interrelation of fatty acid composition in adipose tissue, serum, and liver of dairy cows during the development of fatty liver postpartum. J. Dairy Sci. 83:52-59.

SAS Institute. 2001. SAS/STAT User's Guide, Version 8.0. SAS Institute, Cary, NC.

Schutz, M. M. 1994. Genetic evaluation of somatic cell scores for United States dairy cattle. J. Dairy Sci. 77:2113-2129.

Thomson, N. A., M. J. Auldist, J. K. Kay, A. K. H. MacGibbon, and J. J. Murphy. 2002. On-farm management to modify milk fat composition-A review of experiments undertaken at Dexcel to produce spreadable butter directly from the cow. Proc. N.Z. Soc. Anim. Prod. 62:100-103.

VanSoest, P. J. 1982. Nutritional Ecology of the Ruminant. O \& B Books, Inc., Corvallis, OR. 